\title{
Untangling heavy protein and cofactor isotope effects on enzyme catalyzed hydride transfer
}

DOI:

10.1021/jacs.6b07852

\section{Document Version}

Accepted author manuscript

Link to publication record in Manchester Research Explorer

\section{Citation for published version (APA):}

Longbotham, J. E., Hardman, S., Gorlich, S., Scrutton, N., \& Hay, S. (2016). Untangling heavy protein and cofactor isotope effects on enzyme catalyzed hydride transfer. Journal of the American Chemical Society, 138(41), 13693-13699. https://doi.org/10.1021/jacs.6b07852

\section{Published in:}

Journal of the American Chemical Society

\section{Citing this paper}

Please note that where the full-text provided on Manchester Research Explorer is the Author Accepted Manuscript or Proof version this may differ from the final Published version. If citing, it is advised that you check and use the publisher's definitive version.

\section{General rights}

Copyright and moral rights for the publications made accessible in the Research Explorer are retained by the authors and/or other copyright owners and it is a condition of accessing publications that users recognise and abide by the legal requirements associated with these rights.

\section{Takedown policy}

If you believe that this document breaches copyright please refer to the University of Manchester's Takedown Procedures [http://man.ac.uk/04Y6Bo] or contact uml.scholarlycommunications@manchester.ac.uk providing relevant details, so we can investigate your claim.

\section{OPEN ACCESS}




\title{
Untangling heavy protein and cofactor isotope effects on enzyme- catalyzed hydride transfer
}

\author{
James E. Longbotham ${ }^{\dagger}$, Samantha J. O. Hardman, Stefan Görlich, Nigel S. Scrutton, and Sam Hay* \\ BBSRC/EPSRC Centre for Synthetic Biology of Fine and Speciality Chemicals (SYNBIOCHEM), Manchester Institute of Biotech- \\ nology and School of Chemistry, The University of Manchester, 131 Princess Street, Manchester, M1 7DN, United Kingdom.
}

\begin{abstract}
Heavy' (isotopically-labeled) enzyme isotope effects offer a direct experimental probe of the role of protein vibrations on enzyme-catalyzed reactions. Here we have developed a strategy to generate isotopologues of the flavoenzyme pentaerythritol tetranitrate reductase (PETNR) where the protein and/or intrinsic flavin mononucleotide (FMN) cofactor are isotopically labeled with ${ }^{2} \mathrm{H},{ }^{15} \mathrm{~N}$ and ${ }^{13} \mathrm{C}$. Both the protein and cofactor contribute to the enzyme isotope effect on the reductive hydride transfer reaction, but their contributions are not additive and may partially cancel each other out. However, the isotope effect specifically arising from the FMN suggests that vibrations local to the active site play a role in the hydride transfer chemistry, while the protein-only 'heavy enzyme' effect demonstrates that protein vibrations contribute to catalysis in PETNR. In all cases, enthalpy-entropy compensation plays a major role in minimizing the magnitude of 'heavy enzyme' isotope effects. Fluorescence lifetime measurements of the intrinsic flavin mononucleotide show marked differences between 'light' and 'heavy' enzymes on the ns-ps timescale, suggesting relevant timescale(s) for those vibrations implicated in the 'heavy enzyme' isotope effect on the PETNR reaction.
\end{abstract}

\section{INTRODUCTION}

Proteins are inherently dynamic molecules, exhibiting motions on timescales ranging from bond stretches $\left(\sim 10^{3} \mathrm{~cm}^{-1}\right.$; fs $)$ through to slow domain motions and normal mode vibrations $\left(<1 \mathrm{~cm}^{-1} ; \mathrm{s}\right)$. The functional role of those dynamics that occur on time scales faster than turnover (i.e. $k_{\text {cat }}$ ) remains an open question in enzymology. ${ }^{1-3}$ There has been good progress in establishing the role of ms-ns dynamics such as loop opening/closing during enzyme turnover using NMR approaches, ${ }^{4,5}$ but direct evidence for the coupling of faster (sub-ns) dynamics to chemistry remains illusive and controversial $^{6,7}$ and is based in part on the anomalous temperature dependencies of kinetic isotope effects (KIEs; e.g. $k_{\mathrm{H}} / k_{\mathrm{D}}$ ) on enzyme catalyzed $\mathrm{H}$-transfer reactions. ${ }^{8-10}$

Recently, Schramm and colleagues showed that stable isotope$\left({ }^{2} \mathrm{H},{ }^{13} \mathrm{C}\right.$ and $/$ or $\left.{ }^{15} \mathrm{~N}\right)$ labeled 'heavy' purine nucleoside phosphorylase and HIV-1 protease enzymes have measurably slower reaction kinetics. ${ }^{11-14}$ These data were initially interpreted in terms of the Born-Oppenheimer approximation, where increased protein mass (due to isotopically labeling) alters bond vibrational frequencies without affecting electrostatic properties of the enzyme (ionizable protons were not labeled). The authors suggested that the lower frequency of ( $\mathrm{fs}$ ) bond vibrations in the 'heavy enzymes' may lead to a reduction in conformational sampling and thus chemical barrier crossing, which is proportional to the rate of barrier crossing. Clearly, the 'heavy enzyme' methodology can be used as a powerful tool to study enzyme dynamics and others have since adopted this approach: we extended this approach to perturb the temperature dependence of a KIE on the pentaerythritol tetranitrate reductase (PETNR) catalyzed reductive hydride transfer, ${ }^{15}$ while others have measured isotope effects on 'heavy' alanine racemase ${ }^{16}$ and dihydrofolate reductase (DHFR) ${ }^{17-22}$, and perdeuteration has been long known to significantly reduce the rate of turnover of alkaline phosphatase. ${ }^{23}$ A common finding is that the catalyzed reaction is typically slower in the 'heavier' enzymes.

If isotopic labeling does not perturb protein structure then these 'heavy enzyme' experiments suggest that protein vibrations play some role in controlling the rate of reaction. However, mass perturbation by uniform isotopic (triple) labeling will affect essentially all vibrations within the protein, from bond stretches through to domain motions. Computational studies suggest the vibrations responsible are likely to be fast, ${ }^{14,18}$ which makes experimental verification challenging. One approach is to determine how localized these dynamic effects are - i.e. to determine whether the 'heavy enzyme' effect arises through large-scale protein motions, which are likely to be relatively slow and/or specific vibrations of e.g. single amino acids within the enzyme active site, which are likely to be much faster.

By specifically labeling histidine residues in purine nucleoside phosphorylase, Schramm and colleagues recently demonstrated that much of the 'heavy enzyme' effect in this enzyme arises from these residues, some of which play key roles in substrate binding and catalysis, ${ }^{13}$ and argued that localized fast vibrations couple to the reaction coordinate during this reaction. Similarly, Allemann and colleagues made use of chemical ligation to create isotope hybrids of DHFR and suggested that slow (ms) loop motions in the $\mathrm{N}$-terminal region affect product release while fast vibrations in the C-terminal region directly affect the hydride transfer chemistry. ${ }^{20}$

The reductive half reaction of the Old Yellow enzyme (OYE) PETNR involves hydride transfer from a coenzyme NAD $(\mathrm{P}) \mathrm{H}$ to the N5 atom of a non-covalently bound flavin mononucleotide (FMN) ${ }^{24}$ The enzyme-coenzyme/reactant complex involves $\pi-\pi$ stacking of the $\mathrm{NAD}(\mathrm{P}) \mathrm{H}$ nicotinamide and FMN isoalloxazine moieties, which form a charge-transfer (CT) complex. In addition 
to the FMN, there are 16 'local' active site residues within 5 Å of the bound coenzyme (Figure 1). To investigate whether 'heavy enzyme' isotope effects in PETNR ${ }^{15}$ arises through local and/or global perturbations, in the present study we have used specific labeling of the protein and/or FMN to untangle their individual contributions to 'heavy enzyme' effects. Ultrafast fluorescence spectroscopy is then used to probe the timescales of vibronic coupling between protein and FMN in order to infer likely timescales of those vibrations involved in the 'heavy enzyme' effect in PETNR.

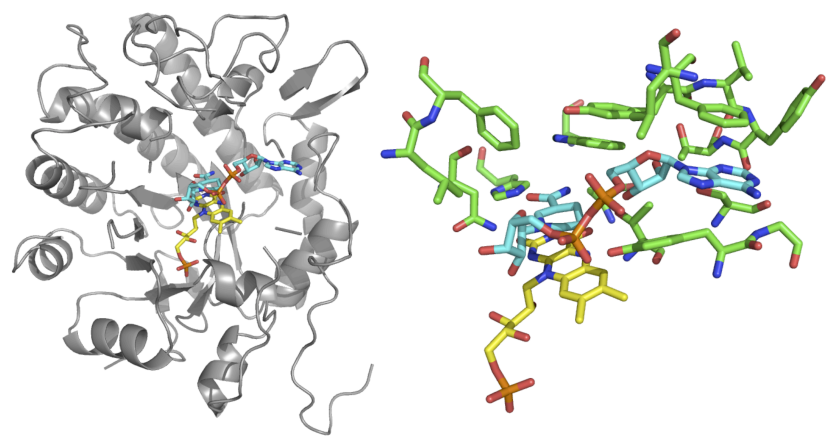

Figure 1. Model of coenzyme-bound PETNR-His8 based on the X-ray crystal structures of PETNR-His8 (PDB 3P62) and $\mathrm{NADH}_{4}$-bound PETNR homolog, morphinone reductase (PDB 2R14). The location of the coenzyme (light blue carbons) was determined using an all-atom alignment of the two structures. The right panel shows the 16 PETNR residues (green carbons) and FMN (yellow carbons) within $5 \AA$ of the bound coenzyme.

\section{RESULTS AND DISCUSSION}

Unlike in our previous mechanistic studies of hydride transfer in PETNR, ${ }^{\text {e.g. }}{ }^{15,25}$ the current work employs PETNR with a Cterminal His 8 tag, which we have used previously for biocatalysis and single molecule studies. ${ }^{26,27}$ Recombinant deuterated and triple-labeled $\left({ }^{2} \mathrm{H},{ }^{13} \mathrm{C},{ }^{15} \mathrm{~N}\right)$ 'heavy' enzymes were prepared by isotopic labeling in E. coli ${ }^{28}$ and the intrinsic FMN cofactor is also labeled during this process. The His-tag allows purification of PETNR using Ni-affinity chromatography and the FMN was subsequently removed and reconstituted in the presence of $\mathrm{KBr}$ using an oncolumn approach (Experimental section). The nomenclature used in the present study, $\mathrm{E}_{\mathrm{i}} \mathrm{F}_{\mathrm{j}}$, denotes the isotopic composition of the enzyme (E) and FMN (F), with i,j either 1 (unlabeled), D (deuterated) or h (triple-labeled).

The isotopic labeling efficiency was investigated using mass spectrometry (Figure S1-S3 in the Supporting Information). Unlabeled PETNR-His 8 has a calculated $\mathrm{mw}=40,586.3 \mathrm{Da}$ and the measured $m / z=40,455.8 \mathrm{Da}$. The $131 \mathrm{Da}$ mass difference is consistent with loss of the $\mathrm{N}$-terminal Met in vivo. Deuterated and triple-labeled enzymes have measured $\mathrm{m} / z=42,618.9$ and 44,627.1 Da respectively, which are $5.3 \%$ and $10.3 \%$ heavier, respectively, than the unlabeled enzyme, similar to other reports of deuterated ${ }^{13}$

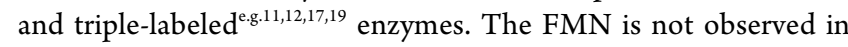
these experiments but NMR experiments suggest that the FMN labeling efficiency is comparable to that of the protein (not shown).

The observed rate of FMN reduction/hydride transfer during the reductive half reaction of PETNR with NADPH and (R)-[4$\left.{ }^{2} \mathrm{H}\right]-\mathrm{NADPH}$ was measured using anaerobic stopped-flow spec-

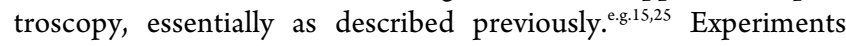
were performed with a saturating ( $5 \mathrm{mM}$ post-mixing) concentra- tion of each coenzyme ${ }^{26}$ over as wide a temperature range (5-40 ${ }^{\circ} \mathrm{C}$ ) as the enzyme would tolerate to magnify any potential differences in rate constants between the 'heavy' and 'light' enzymes.

The reductive half reaction of PETNR involves coenzyme binding followed by hydride transfer, which is concomitant with FMN reduction. Coenzyme binding occurs in 2 steps $^{29}$ and can be monitored by following the formation of the $\mathrm{CT}$ absorbance at $550 \mathrm{~nm}$. The kinetics associated with NADPH binding to $\mathrm{E}_{1} \mathrm{~F}_{1}$ and $\mathrm{E}_{\mathrm{h}} \mathrm{F}_{\mathrm{h}}$ forms of PETNR were examined at $10{ }^{\circ} \mathrm{C}$ (Figure 2). The observed rate of $\mathrm{NADPH}$ binding is not significantly different in $\mathrm{EF}_{1} \mathrm{~F}_{1}$ and $\mathrm{E}_{\mathrm{h}} \mathrm{F}_{\mathrm{h}}$ PETNR, suggesting that isotopic substitution of the enzyme does not measurably perturb coenzyme capture and binding. However, the first order rate of CT decay, which corresponds to FMN reduction/hydride transfer, differs with $k=11.36 \pm 0.12$ and 10.96 $\pm 0.22 \mathrm{~s}^{-1}$ for $\mathrm{E}_{\mathrm{l}} \mathrm{F}_{1}$ and $\mathrm{E}_{\mathrm{h}} \mathrm{F}_{\mathrm{h}}$ PETNR, respectively, corresponding to an enzyme $\mathrm{KIE}\left(\mathrm{E}_{1} \mathrm{~F}_{1} / \mathrm{E}_{\mathrm{h}} \mathrm{F}_{\mathrm{h}}\right)$ of $1.036 \pm 0.031$. While this value is close to unity, it is of similar magnitude to that measured previously for FMN reduction in wild-type PETNR ${ }^{15}$ and later in the current study (Figure S5).

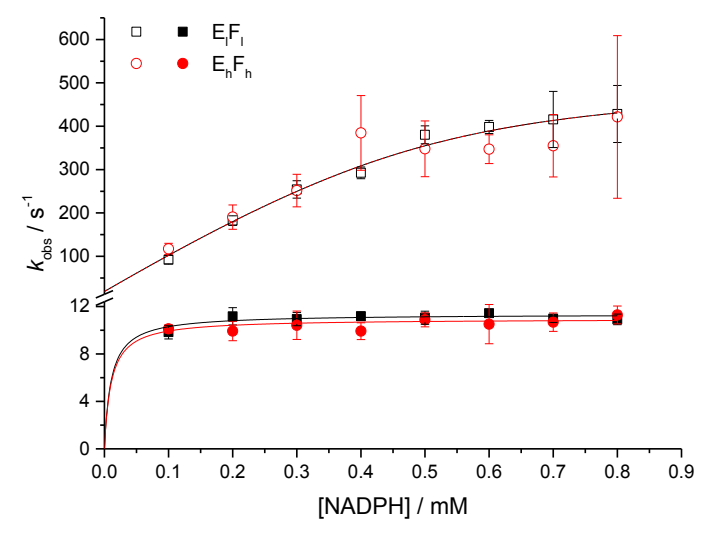

Figure 2. The observed rate of FMN-NADPH charge transfer formation (open symbols) and decay (filled symbols) in $20 \mu \mathrm{M}$ 'light' $\left(\mathrm{E}_{\mathrm{l}} \mathrm{F}_{\mathrm{l}}\right.$; black) and $10 \mu \mathrm{M}$ 'heavy' $\left(\mathrm{E}_{\mathrm{h}} \mathrm{F}_{\mathrm{h}}\right.$; red) PETNR, measured at $5^{\circ} \mathrm{C}$. The data are globally fitted as described in Table S2.

The rate of FMN reduction/hydride transfer (monitored at 465 $\mathrm{nm}$ ) of $\mathrm{E}_{1} \mathrm{~F}_{1}$ was next compared to the wild-type non-His tagged enzyme (wt- $\mathrm{E}_{1} \mathrm{~F}_{1}$; data taken from ref 15 ) and unlabeled PETNRHis 8 where the FMN was removed and reconstituted with unlabeled commercially obtained FMN (denoted $\mathrm{E}_{1} \mathrm{~F}_{1}^{*}$ ). An Arrhenius plot of the observed rate constants shows the data measured with NADPH are essentially superimposable (Figure 3 ). The $\mathrm{E}_{1} \mathrm{~F}_{1}$ and $\mathrm{E}_{\mathrm{l}} \mathrm{F}_{1} *$ data measured with $(R)-\left[4-{ }^{2} \mathrm{H}\right]-\mathrm{NADPH}$ are also very similar (Figure 3, Table $\mathrm{S} 1$ ), suggesting that the removal and reincorporation of the FMN does not measurably perturb the FMN reduction kinetics of PETNR.

Next, the intrinsic 'heavy' FMN was removed from 'heavy' $\mathrm{E}_{h} \mathrm{~F}_{h}$ PETNR and replaced with unlabeled FMN to create an $\mathrm{E}_{\mathrm{h}} \mathrm{F}_{1}$ mixedlabel isotopologue. Likewise, $\mathrm{E}_{\mathrm{l}} \mathrm{F}_{\mathrm{h}}$ PETNR was created using triplelabeled FMN (extracted from $\mathrm{E}_{\mathrm{h}} \mathrm{F}_{\mathrm{h}}$ PETNR) incorporated into unlabeled enzyme. The reductive hydride transfer kinetics of the variously labeled PETNR samples were again measured with both NADPH and (R)-[4- $\left.{ }^{2} \mathrm{H}\right]-\mathrm{NADPH}$. The heavy enzyme KIEs of these samples were next compared by measuring FMN reduction by both NADPH and $(R)-\left[4-{ }^{2} \mathrm{H}\right]-\mathrm{NADPH}$ (Figure S5). As the enzyme KIE is small and temperature dependent, ${ }^{15}$ these data are interpreted by comparison of activation parameters rather than 
observed enzyme KIEs. Arrhenius plots (Figures 3 and S4) are noticeably non-linear when data at $T>308 \mathrm{~K}$ are considered (which we have previously neglected $\left.{ }^{15,25}\right)$, so these data were fitted to the non-linear Eyring-based function:

$$
\begin{aligned}
\ln k_{\text {obs }} & =\ln \left(k_{\mathrm{B}} T / h\right)-\left(\Delta H_{T_{0}}^{\neq}+\Delta C_{p}^{\neq}\left(T-T_{0}\right)\right) / R T \\
& +\left(\Delta S_{T_{0}}^{\neq}+\Delta C_{p}^{\neq} \ln \left(T / T_{0}\right)\right) / R
\end{aligned}
$$

where $\Delta C_{\mathrm{p}}{ }^{\dagger}$ is the difference in heat capacity between the reactant and transition states, $\Delta H_{\mathrm{T} 0}{ }^{\ddagger}$ and $\Delta S_{\mathrm{T} 0}{ }^{\ddagger}$ are the activation enthalpy and entropy, respectively at a reference temperature $T_{0}(298 \mathrm{~K}$ in this study) and $k_{\mathrm{B}}, h$ and $R$ are the Boltzmann, Planck and ideal gas constants, respectively. ${ }^{30,31}$ Fitted parameters are given in Table 1. There is little variation in the $\Delta C_{\mathrm{p}}{ }^{\dagger}$ values, which fall between -0.5 and $-0.9 \mathrm{~kJ} \mathrm{~mol}^{-1} \mathrm{~K}^{-1}$. These values give rise to the small degree of curvature observed in the Arrhenius plots in Figures 3 and S4.

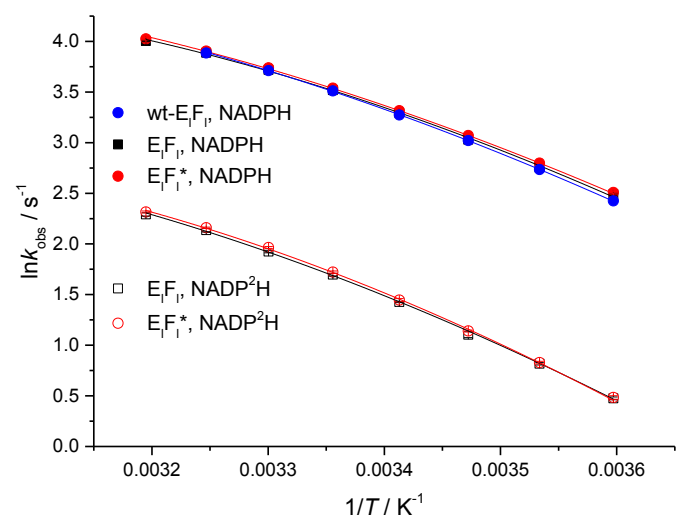

Figure 3. Arrhenius plot of the observed rate of hydride transfer from $\mathrm{NADPH}$ and $(R)-\left[4-{ }^{2} \mathrm{H}\right]-\mathrm{NADPH}$ to the FMN in wild-type (wt- $\mathrm{E}_{\mathrm{L}} \mathrm{F}_{\mathrm{L}}$ ), His-tagged $\left(\mathrm{E}_{\mathrm{L}} \mathrm{F}_{\mathrm{L}}\right)$, and FMN-reconstituted $\left(\mathrm{E}_{\mathrm{L}} \mathrm{F}_{\mathrm{L}}{ }^{*}\right)$ PETNR. These data are fitted to Eq 1, with fitted parameters given in Table 1 and additional data are shown in Figure S4.

The apparent activation enthalpies and entropies are compared in Figure 4. The $\Delta H_{\mathrm{T} 0}{ }^{\ddagger}$ values differ by $\sim 3 \mathrm{~kJ} \mathrm{~mol}^{-1}$ between the PETNR isotopologues for the reactions with both NADPH and (R)- $\left[4-{ }^{2} \mathrm{H}\right]-\mathrm{NADPH}$, which corresponds to a $\mathrm{KIE}=$ $\exp \left(\Delta \Delta H_{\mathrm{TO}}{ }^{\ddagger} / R T_{0}\right) \sim 3.4$. The magnitude of the observed enzyme KIE is much smaller than this due to almost complete entropyenthalpy compensation (Figure 4).

Like our previous study of 'heavy' PETNR, ${ }^{15}$ we observe a decrease in activation enthalpy in 'heavy' vs. 'light' enzymes (Figure 4). Conversely, the deuterated enzymes $\left(E_{D} F_{D}\right)$ show larger values of $\Delta H_{\mathrm{T} 0}{ }^{\ddagger}$ and $\Delta S_{\mathrm{T} 0}{ }^{\ddagger}$ than $\mathrm{E}_{\mathrm{L}} \mathrm{F}_{\mathrm{L}}$. The behavior of the mixed-label species also differ, with the magnitude of $\Delta H_{\mathrm{T} 0}{ }^{\dagger}$ ordered: $\mathrm{El}_{\mathrm{l}} \mathrm{F}_{\mathrm{h}}>\mathrm{E}_{\mathrm{l}} \mathrm{F}_{1}$ $>\mathrm{E}_{\mathrm{h}} \mathrm{F}_{\mathrm{h}}>\mathrm{E}_{\mathrm{h}} \mathrm{F}_{1}$ for the reactions with NADPH. The $(R)-\left[4-^{2} \mathrm{H}\right]-$ $\mathrm{NADPH}$ data is more clustered, but the $\mathrm{E}_{\mathrm{h}} \mathrm{F}_{1}$ again has clearly the highest $\Delta H_{\mathrm{TO}}{ }^{\ddagger}$. Like our previous report, ${ }^{15}$ the coenzyme KIEs are more temperature dependent (larger $\Delta \Delta H_{\mathrm{T} 0}{ }^{\ddagger}$ ) in heavy PETNR, but the contributions from the protein and FMN cofactor do not appear to be additive, with the mixed-label $\mathrm{E}_{\mathrm{h}} \mathrm{F}_{1}$ and $\mathrm{E}_{\mathrm{l}} \mathrm{F}_{\mathrm{h}}$ isotopologues showing larger $\Delta \Delta H_{\mathrm{T} 0}{ }^{\ddagger}$ values than $\mathrm{E}_{\mathrm{h}} \mathrm{F}_{\mathrm{h}}$ PETNR. Together, these data show that both the protein and FMN contribute to the 'heavy enzyme' effect in PETNR, and suggest that the nature of the isotope $\left({ }^{2} \mathrm{H} v s .{ }^{13} \mathrm{C} v s .{ }^{15} \mathrm{~N}\right)$ and the location of the isotopic substitution can perturb the reaction in different ways such that these effects may (partially) cancel each other out. The isotope effect spe- cifically arising from the FMN $\left(\mathrm{E}_{\mathrm{l}} \mathrm{F}_{\mathrm{h}}\right)$ suggests that vibrations local to the active site play a role in the hydride transfer chemistry, while the protein-only 'heavy enzyme' effect on the $\mathrm{E}_{\mathrm{h}} \mathrm{F}_{1}$ reaction shows how protein vibrations can contribute to catalysis. These data do not show whether such vibrations promote or inhibit the reaction (as has been suggested for DHFR catalysis ${ }^{3}$ ), but if they give rise to the temperature dependence of the coenzyme $\operatorname{KIE}\left(\Delta \Delta H^{\dagger}\right)$, then they are likely to be promoting as the reaction of PETNR with $\mathrm{NADH}$ is significantly slower that the reaction with NADPH and $\Delta \Delta H^{\ddagger, N A D H}<<\Delta \Delta H^{\ddagger, N A D P H} .25$

\begin{tabular}{|c|c|c|c|}
\hline & $\begin{array}{l}\Delta H_{\mathrm{T}_{0}^{\ddagger}} \\
\left(\mathrm{kJ} \mathrm{mol}^{-1}\right)\end{array}$ & $\begin{array}{l}\Delta S_{\mathrm{T}^{\ddagger}} \\
\left(\mathrm{J} \mathrm{mol}^{-1} \mathrm{~K}^{-1}\right)\end{array}$ & $\begin{array}{l}\Delta C_{\mathrm{P}}^{\ddagger} \\
\left(\mathrm{kJ} \mathrm{mol}^{-1} \mathrm{~K}^{-1}\right)\end{array}$ \\
\hline \multicolumn{4}{|c|}{ NADPH } \\
\hline wt- $\mathrm{El}_{1} \mathrm{~F}_{1}^{\mathrm{a}}$ & $29.6 \pm 0.2$ & $-111.7 \pm 0.6$ & $-0.53 \pm 0.03$ \\
\hline $\mathrm{E}_{1} \mathrm{~F}_{1}$ & $27.8 \pm 0.5$ & $-122.3 \pm 1.5$ & $-0.58 \pm 0.08$ \\
\hline $\mathrm{E}_{1} \mathrm{~F}_{1}^{*}$ & $28.0 \pm 0.3$ & $-121.6 \pm 0.9$ & $-0.52 \pm 0.04$ \\
\hline $\mathrm{E}_{\mathrm{D}} \mathrm{F}_{\mathrm{D}}$ & $28.5 \pm 0.5$ & $-120.1 \pm 1.8$ & $-0.56 \pm 0.08$ \\
\hline $\mathrm{E}_{\mathrm{h}} \mathrm{F}_{\mathrm{h}}$ & $27.1 \pm 0.3$ & $-124.7 \pm 0.9$ & $-0.61 \pm 0.05$ \\
\hline $\mathrm{E}_{\mathrm{h}} \mathrm{F}_{1}$ & $26.1 \pm 0.5$ & $-127.8 \pm 1.6$ & $-0.74 \pm 0.09$ \\
\hline $\mathrm{E}_{l} \mathrm{~F}_{\mathrm{h}}$ & $28.6 \pm 0.4$ & $-120.0 \pm 1.2$ & $-0.49 \pm 0.06$ \\
\hline \multicolumn{4}{|c|}{$(R)-\left[4-{ }^{2} \mathrm{H}\right]-\mathrm{NADPH}$} \\
\hline wt $-\mathrm{E}_{1} \mathrm{~F}_{1}{ }^{a}$ & $33.8 \pm 0.1$ & $-119.2 \pm 0.5$ & $-0.85 \pm 0.04$ \\
\hline \multirow[t]{2}{*}{$\mathrm{E}_{\mathrm{l}} \mathrm{F}_{1}^{\mathrm{b}}$} & $33.8 \pm 0.1$ & $-118.2 \pm 0.4$ & $-0.62 \pm 0.02$ \\
\hline & $33.7 \pm 0.3$ & $-117.8 \pm 1.2$ & $-0.58 \pm 0.05$ \\
\hline \multirow[t]{2}{*}{$\mathrm{E}_{1} \mathrm{~F}_{1}^{* \mathrm{~b}}$} & $34.3 \pm 0.3$ & $-116.2 \pm 1.0$ & $-0.76 \pm 0.07$ \\
\hline & $34.1 \pm 0.4$ & $-116.1 \pm 1.3$ & $-0.68 \pm 0.09$ \\
\hline $\mathrm{E}_{\mathrm{D}} \mathrm{F}_{\mathrm{D}}$ & $35.6 \pm 0.3$ & $-111.9 \pm 1.0$ & $-0.50 \pm 0.06$ \\
\hline $\mathrm{E}_{\mathrm{h}} \mathrm{F}_{\mathrm{h}}$ & $34.1 \pm 0.7$ & $-116.9 \pm 2.3$ & $-0.69 \pm 0.11$ \\
\hline $\mathrm{E}_{\mathrm{h}} \mathrm{F}_{1}$ & $34.3 \pm 0.8$ & $-115.6 \pm 2.8$ & $-0.78 \pm 0.11$ \\
\hline $\mathrm{E}_{\mathrm{l}} \mathrm{F}_{\mathrm{h}}$ & $36.4 \pm 0.9$ & $-109.5 \pm 3.1$ & $-0.89 \pm 0.16$ \\
\hline \multicolumn{4}{|c|}{ Isotope effect: $\mathrm{NADP}^{2} \mathrm{H}-\mathrm{NADPH}$} \\
\hline \multirow[t]{2}{*}{$\mathrm{E}_{1} \mathrm{~F}_{1}$} & $6.0 \pm 0.6$ & $4.1 \pm 1.9$ & $-0.03 \pm 0.11$ \\
\hline & $5.9 \pm 0.8$ & $4.4 \pm 2.7$ & $0.00 \pm 0.13$ \\
\hline \multirow[t]{2}{*}{$\mathrm{E}_{\mathrm{l}} \mathrm{F}_{1}^{*}$} & $6.3 \pm 0.6$ & $5.4 \pm 1.9$ & $-0.23 \pm 0.11$ \\
\hline & $6.1 \pm 0.9$ & $5.5 \pm 2.2$ & $-0.16 \pm 0.13$ \\
\hline $\mathrm{E}_{\mathrm{D}} \mathrm{F}_{\mathrm{D}}$ & $7.1 \pm 0.8$ & $8.2 \pm 2.8$ & $0.06 \pm 0.14$ \\
\hline $\mathrm{E}_{\mathrm{h}} \mathrm{F}_{\mathrm{h}}$ & $6.9 \pm 0.9$ & $7.8 \pm 3.2$ & $-0.08 \pm 0.16$ \\
\hline $\mathrm{E}_{\mathrm{h}} \mathrm{F}_{1}$ & $8.2 \pm 1.3$ & $12.3 \pm 4.3$ & $-0.05 \pm 0.19$ \\
\hline $\mathrm{E}_{\mathrm{l}} \mathrm{F}_{\mathrm{h}}$ & $7.9 \pm 1.3$ & $10.5 \pm 4.3$ & $-0.40 \pm 0.22$ \\
\hline
\end{tabular}

\section{Table 1. Selected kinetic parameters}

${ }^{a}$ The wild-type PETNR without His tag; data taken from ref ${ }^{15}$. ${ }^{\mathrm{b}}$ These data were measured in duplicate with separately prepared enzyme and deuterated coenzyme samples.

Direct experimental observation of the timescale(s) of any vibrations that couple the protein and/or FMN to the chemical coordinate is necessary in order to firmly establish the theoretical origin of the 'heavy enzyme' effect in PETNR. Ultrafast spectroscopy allows experimental access to these timescales, so the intrinsic FMN was used as a fluorescent reporter of the (local) environment in the 
active site of PETNR. A similar approach by the Klinman group using intrinsic Trp reporters showed evidence for ns-ps dynamics, which track with the catalytic activity of a thermophilic alcohol dehydrogenase. . $^{32,33}$
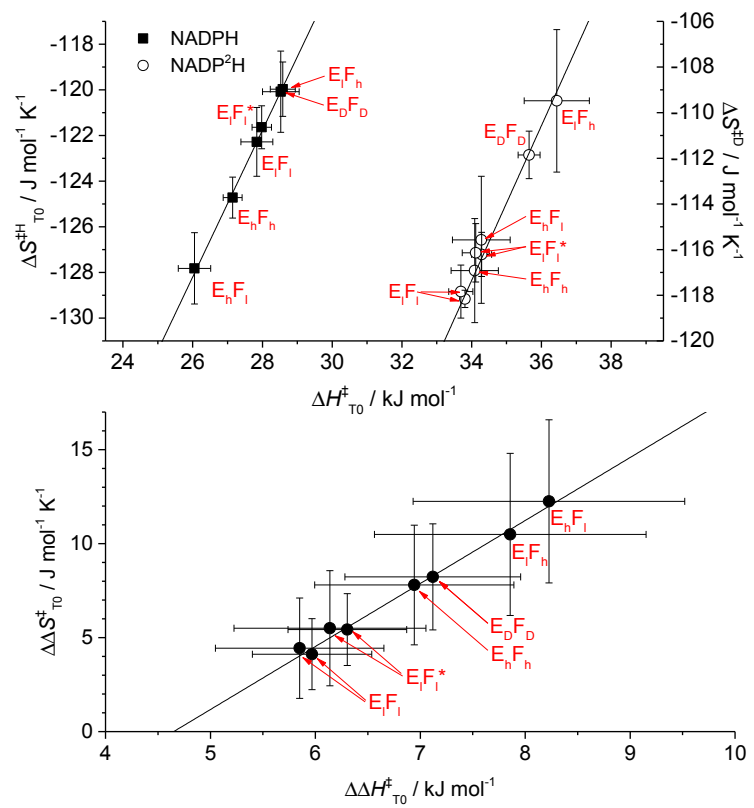

Figure 4. Top, The relationship between the apparent activation enthalpy and entropy values determined for the reactions of NADPH (filled squares) and (R)-[4- $\left.{ }^{2} \mathrm{H}\right]-\mathrm{NADPH}$ (open circles) with the PETNR isotopologues labeled in red. The solid lines are linear fits of each data set to guide the eye. Bottom, The relationship between the differences (coenzyme KIE; NADP ${ }^{2} \mathrm{H}-\mathrm{NADPH}$ ) in apparent activation enthalpy and entropy.

The steady state fluorescence emission spectra of $E_{1} F_{1}, E_{D} F_{D}$ and $\mathrm{E}_{\mathrm{h}} \mathrm{F}_{\mathrm{h}}$ PETNR are similar (Figure S6), but the singlet excited state of FMN within PETNR is efficiently and rapidly quenched, likely by reversible electron transfer from neighboring aromatic (Trp and Tyr) residues, ${ }^{34}$ so time-resolved measurements are required to properly characterize the FMN fluorescence/excited state behavior. The fluorescence decay of the intrinsic FMN in light $\left(\mathrm{E}_{1} \mathrm{~F}_{1}\right)$ and heavy $\left(E_{h} F_{h}\right)$ PETNR was measured on the ps timescale using a fluorescence upconversion spectrometer with $\sim 0.5$ ps resolution. The majority of the fluorescence decays with two components of $\tau$ $\sim 5$ and $\tau \sim 30$ ps and these lifetimes do not greatly differ between light and heavy PETNR (Figures 5 and S7). Transient absorption measurements made over the same timescale also show little difference between the excited state absorption and ground state recovery of $\mathrm{E}_{1} \mathrm{~F}_{1}$ and $\mathrm{E}_{\mathrm{h}} \mathrm{F}_{\mathrm{h}}$ PENTR (Figure S8, Table S3) and shows ground state recovery occurring on a similar timescale $(\sim 8$ and $\sim 80$ ps) to the fluorescence decays in Figure 5.

As PETNR also has some residual fluorescence on longer timescales, time-correlated single photon counting measurements were performed in order to investigate the longer ns fluorescence components. These decays are multiphasic and show pronounced differences in individual lifetimes and/or (sub)populations between the PETNR isotopologues (Figure 6). The lifetimes of light $\left(F_{1}\right)$ and heavy $\left(F_{h}\right)$ FMN in solution (i.e. extracted from PETNR) are similar (Figure 6 and Table S4), suggesting that the differences in fluorescence decay observed between enzyme isotopologues likely arises through altered protein-FMN interactions. The data in Fig- ure 6 are fitted using a model-free distribution of lifetime analysis (Figure S8, table S4), which shows the data are principally comprised of fluorescent components with lifetimes of $\sim 5 \mathrm{~ns}$ and $\sim 0.2$ ns. The population is shifted towards the longer-lifetime species in $\mathrm{E}_{\mathrm{l}} \mathrm{F}_{1}$ and towards the shorter lifetime species in the $\mathrm{E}_{\mathrm{D}} \mathrm{F}_{\mathrm{D}}, \mathrm{E}_{\mathrm{h}} \mathrm{F}_{\mathrm{h}}$ and $\mathrm{E}_{l} \mathrm{~F}_{\mathrm{h}}$ PETNR. The $\mathrm{E}_{\mathrm{l}} \mathrm{F}_{\mathrm{h}}$ PETNR has an intermediate behavior.

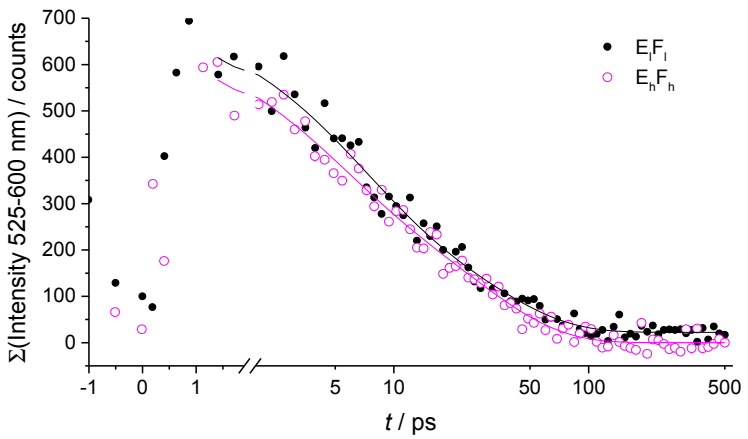

Figure 5. Picosecond fluorescence lifetime decays of the intrinsic FMN in light $\left(\mathrm{E}_{\mathrm{l}} \mathrm{F}_{\mathrm{l}}\right)$ and heavy $\left(\mathrm{E}_{\mathrm{h}} \mathrm{F}_{\mathrm{h}}\right)$ PETNR after excitation at $375 \mathrm{~nm}$. The data (open circles) are fitted to a double exponential function with $\tau_{1}=$ $29.1 \pm 5.6 \mathrm{ps}$ and $\tau_{2}=5.6 \pm 1.3 \mathrm{ps}$ in $\mathrm{E}_{1} \mathrm{~F}_{1}$ and $\tau_{1}=26.7 \pm 3.6 \mathrm{ps}$ and $\tau_{2}=$ $4.1 \pm 1.1 \mathrm{ps}$ in $\mathrm{E}_{\mathrm{h}} \mathrm{F}_{\mathrm{h}}$ PETNR. Both lifetimes are of similar amplitude and there is no significant difference in amplitudes/populations between the two samples. Measurements were performed at room temperature.

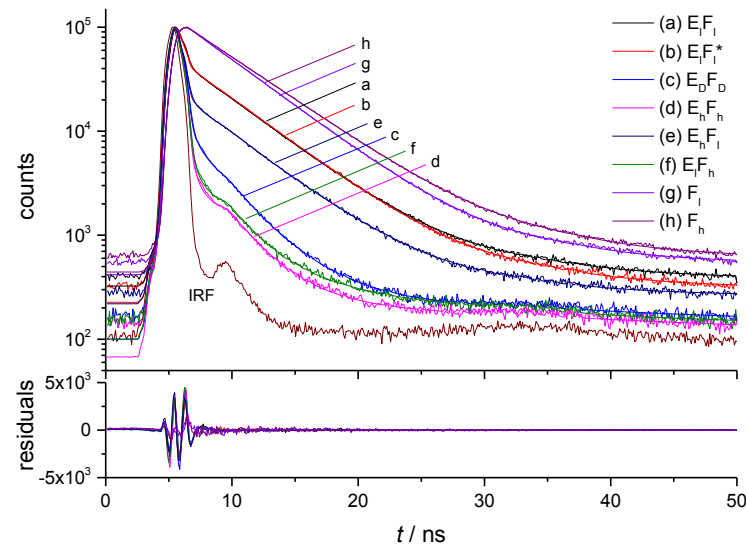

Figure 6. Nanosecond fluorescence lifetime decays of various isotopologues of FMN in solution and when bound to PETNR. All data were fitted by reconvolution using the instrument response function (IRF) shown, and residuals are shown below. The fitting is discussed in the main text and lifetime components are given in Table S4. All measurements were performed at room temperature and any unbound FMN was removed from the enzyme samples by gel filtration immediately prior to the measurement. Samples were excited at $474 \mathrm{~nm}$ and their emission measured at $550 \mathrm{~nm}$.

In addition to reductive electron transfer ${ }^{34}$ and fluorescence, internal conversion and intersystem crossing could play a role in depopulating the longer-lived FMN singlet excited state population. Intersystem crossing in solvated flavins is thought to involve a vibronic spin-orbit mechanism, which is sensitive to the environment. ${ }^{35}$ One explanation for the variable quenching of ns fluorescence in PETNR isotopologues (Figure 6) is that there is vibronic coupling of protein vibrational mode(s) to singlet excited state FMN, which is altered upon isotopic substitution of the FMN and/or protein. Indeed, 'Butterfly' bending motions have been shown to control the excited-state dynamics of flavins as the excited 
state is rapidly deactivated when the isoalloxazine is in a bent conformation. ${ }^{36}$ Alternatively, isotopic substitution of the protein could affect the rate or efficiency of reductive electron transfer from aromatic side chains to FMN if protein vibrations mediate the electron transfer. ${ }^{37,38}$ In either case, the similar fluorescence of free $F_{l}$ and $F_{h}$ FMN (Figure 6) show that the protein must play a role in the quenching process. Both mechanisms also violate the BornOppenheimer approximation.

In order to compete with fluorescence, the frequencies of those vibration(s) involved in the quenching of the FMN excited state must be on a similar or faster timescale to fluorescence - approximately sub-10 ns. This rules out slow global motions involving e.g. active site loop opening/closing. The fast ps excited state decay is not measurably different in heavy and light PETNR (Figure 5), which suggests either the FMN excited state population involved is not vibrationally coupled to the protein, or the vibrations involved are slower than these ultrafast decays processes(es).

What then is the mechanistic origin(s) of the heavy enzyme KIE on hydride transfer catalyzed by PETNR? Heavy isotope labeling is expected to reduce the frequencies of harmonic bond vibrations, while having minimal effect on electrostatics. In enzymes where vibrations lead to active site 'compression' such as the transient reduction in hydrogen donor-acceptor atoms, which has been suggested for OYEs such as PETNR,,$^{1,25,39-41}$ then perturbation of such vibrations can lead to altered reaction kinetics by altering the probability of transition state formation and/or the rate of transition state recrossing. ${ }^{17,18,42}$ Slower dynamics will also be affected by mass perturbation, which may lead to altered substrate/product binding and release kinetics. ${ }^{20,21}$ We have previously identified computationally specific vibrational modes that reduce the donor (NADH C4)-acceptor (FMN N5) distance in the PETNR homolog morphinone reductase. ${ }^{41}$ An out-of-plane bending of the nicotinamide moiety of $\mathrm{NADH}$ was identified as being the key 'promoting vibration' in this reaction and clearly inherent $\mathrm{NAD}(\mathrm{P}) \mathrm{H}$ vibrations will not be directly affected by protein and/or FMN isotopic labeling. However, the FMN will undergo low frequency 'butterfly' bending motions, which are likely sensitive to isotopic labeling of both protein and FMN, ${ }^{36}$ and donor-acceptor 'compression' will be most effective when these vibrations are resonant and anticorrelated with nicotinamide bending vibration(s). Consequently, the PETNR heavy enzyme effect may arise through perturbation of low frequency vibrational modes in the FMN, which alters the probability of transition state formation and thus $\mathrm{H}$-transfer. $\mathrm{H}$ bonding of the nicotinamide by active site residues such as His186 will also have some affect on low frequency vibrations in the coenzyme and thus the protein-only heavy enzyme KIE may also arise, in part, through these interactions. The relatively small magnitude of the heavy enzyme KIE in PETNR may arise as key vibration(s) in the nicotinamide are not directly perturbed by mass modulation of the protein and/or FMN. Labeling of the NADPH will be investigated in future work.

\section{CONCLUSIONS}

While there is no direct link between the fluorescence and hydride transfer experiments presented here, they both show mass perturbation effects. Fluorescence quenching of the FMN suggests there is mass-dependent vibronic coupling of protein and FMN motions to FMN electronically excited state(s) while heavy enzyme isotope effects suggest that protein and FMN vibrations in the reactant and/or transition state affect the rate of hydride trans- fer. If similar vibrational mode(s) are involved in both processes, then these are likely to be on the ns-fs timescale and, at least in part, localized to the active site. FMN 'butterfly' bending motions are a good candidate for such vibrational mode(s). The 'heavy enzyme' isotope effects observed when only the protein is labeled $\left(\mathrm{E}_{\mathrm{H}} \mathrm{F}_{\mathrm{L}}\right)$ also clearly demonstrate that protein vibrations contribute to catalysis in PETNR.

\section{EXPERIMENTAL}

All materials were obtained from Sigma-Aldrich (St. Louis, $\mathrm{MO}$ ), except $\mathrm{NADP}^{+}$and $\mathrm{NADPH}$, which were obtained from Melford Laboratories (Chelsworth, U.K.) and all isotopicallyenriched compounds, which were obtained from Goss Scientific Ltd (Crewe, U.K.) except ${ }^{13} \mathrm{C}_{6},{ }^{2} \mathrm{H}_{7}$-glucose, which was from SigmaAldrich.

PETNR with a C-terminal His8 tag was expressed and purified by Ni-affinity chromatography as described previously. ${ }^{28}$ Isotopic labeling was performed by expression in E. coli grown in M9 minimal media supplemented with $2 \mu \mathrm{g} \mathrm{mL}^{-1}$ thiamine hydrochloride, essentially as described previously for the wild-type enzyme. ${ }^{15}$ Deuteration was performed with ${ }^{2} \mathrm{H}_{7}$-glucose and $\mathrm{D}_{2} \mathrm{O}$, while triple labeling was performed with ${ }^{13} \mathrm{C}_{6},{ }^{2} \mathrm{H}_{7}$-glucose, $\left({ }^{15} \mathrm{NH}_{4}\right)_{2} \mathrm{SO}_{4}$ and $\mathrm{D}_{2} \mathrm{O}$. Samples were purified and prepared in $\mathrm{H}_{2} \mathrm{O}$ (cf. $\mathrm{D}_{2} \mathrm{O}$ ) solutions to facilitate back-exchange of deuterated ionizable residues prior to characterization. FMN was removed from, and reconstituted into PETNR-His 8 while the enzyme was bound to a $5 \mathrm{ml} \mathrm{Ni}$ IDA agarose column (Generon, Maidenhead, UK) at $4{ }^{\circ} \mathrm{C}$, essentially as described recently for 5-deazaFMN incorporation into nitric oxide synthase. ${ }^{43}$ Briefly, the FMN was extracted with $2 \mathrm{M}$ $\mathrm{KBr}, 50 \mathrm{mM}$ sodium acetate, $\mathrm{pH} 5.5$, which was passed over the column at a flow rate of $\sim 0.5 \mathrm{ml} \mathrm{min}{ }^{-1}$ for $\sim 3 \mathrm{~h}$ until no yellow color was observed on the column or in the flow through. The column was then washed with $50 \mathrm{mM}$ potassium phosphate, $\mathrm{pH}$ 8. ApoPETNR was reconstituted with FMN by recirculating a solution of $\sim 25 \mathrm{~mL}$ of $\sim 0.1 \mathrm{mM} F M N$ in $50 \mathrm{mM}$ potassium phosphate, $\mathrm{pH} 8$ through the column overnight. The following day, the column was washed with $50 \mathrm{~mL}$ of $50 \mathrm{mM}$ potassium phosphate, $\mathrm{pH} 8$ in order to remove any unbound FMN prior to elution of PETNR with 500 $\mathrm{mM}$ imidazole, $50 \mathrm{mM}$ potassium phosphate, $\mathrm{pH} 8$.

Mass spectrometry was performed on an Agilent 6510 Q-TOF instrument. All experiments were performed in $50 \mathrm{mM}$ potassium phosphate, $\mathrm{pH}$ 7. Stopped-flow experiments were made with a HiTech Scientific (TgK Scientific, Bradford on Avon, U.K.) stoppedflow spectrophotometer housed within an anaerobic glovebox (Belle Technology; <5 ppm O2). Spectral changes accompanying FMN reduction were monitored by absorption at $465 \mathrm{~nm}$ using a saturating concentration of $5 \mathrm{mM} \mathrm{NADPH}$ or $(R)-\left[4-{ }^{2} \mathrm{H}\right]$ $\mathrm{NADPH}$, prepared as described previously. ${ }^{25,44}$ Typically 5 measurements were taken for each reaction condition and transients were fitted using a single-exponential function. Quoted rate constants are the average values \pm 1 standard deviation.

Ultrafast spectroscopy was performed with a Ti:sapphire amplifier system (Spectra Physics Solstice Ace) producing $800 \mathrm{~nm}$ pulses (power $6 \mathrm{~mJ}$ ) at $1 \mathrm{kHz}$ with $100 \mathrm{fs}$ pulse duration. A portion of the amplifier output was used to pump a Topas Prime OPA with associated NirUVis unit, which generated the excitation beam. A broadband transient absorption spectrometer, 'Helios' (Ultrafast systems LLC), was used to collect data from $\sim 1$ to 2900 ps after excitation with $1 \mathrm{uJ}$ at $375 \mathrm{~nm}$, with a time resolution of $\sim 0.3 \mathrm{ps}$. The probe beam consisted of a white light continuum generated in 
a sapphire crystal. A broadband fluorescence up-conversion spectrometer with CCD detector, 'Halcyone' (Ultrafast Systems LLC) was used to record emission spectra from $\sim 1$ to 500 ps after excitation with $0.5 \mathrm{uJ}$ at $375 \mathrm{~nm}$, with a time resolution of $\sim 0.5 \mathrm{ps}$. Samples were contained in a $2 \mathrm{~mm}$ pathlength quartz cell (at room temperature) and stirred to prevent photodegredation. The concentration was adjusted to give an absorbance of $\sim 0.12$ at $464 \mathrm{~nm}$. Time-correlated single photon counting measurements were performed with an Edinburgh Instruments FLS920 spectrometer (Edinburgh, UK) with double excitation and emission monochromators and a red-sensitive cooled photomultiplier detector. An EPL $474 \mathrm{~nm}$ pulsed diode laser (Edinburgh Instruments) was used for excitation. Data were analysed using a lifetime distribution analysis with IRF reconvolution using the FAST software supplied by Edinburgh Instruments.

\section{ASSOCIATED CONTENT}

\section{Supporting Information}

The Supporting Information is available free of charge on the ACS Publications website.

Tabulated rate constants and additional fitting parameters, additional characterization and kinetic analysis.

\section{AUTHOR INFORMATION}

\section{Corresponding Author}

*Sam.Hay@manchester.ac.uk

\section{Present Addresses}

†Department of Cellular and Molecular Pharmacology, University of California San Francisco

\section{Funding Sources}

This work was funded by the UK Biotechnology and Biological Sciences Research Council (BBSRC; BB/M007065/1, BB/H021523/1 \& $\mathrm{BB} / \mathrm{M} 011658 / 1)$ and N.S.S is an Engineering and Physical Sciences Research Council (EPSRC) Established Career Research Fellow (EP/J020192/1).

\section{ACKNOWLEDGMENT}

Mass spectrometry was performed by the Manchester Biomolecular Analysis Facility

\section{ABBREVIATIONS}

CT, charge transfer; DHFR, dihydrofolate reductase; EF, enzyme flavin; FMN, flavin mononucleotide; KIE, kinetic isotope effect; $\mathrm{NAD}(\mathrm{P}) \mathrm{H}$, reduced nicotinamide adenine dinucleotide (phosphate).

\section{REFERENCES}

(1) Hay, S.; Scrutton, N. S. Nature Chem. 2012, 4, 161-168.

(2) Klinman, J. P.; Kohen, A. J. Biol. Chem. 2014, 289, 30205-

(3) Luk, L. Y.; Loveridge, E. J.; Allemann, R. K. Phys. Chem. Chem. Phys. 2015, 17, 30817-30827.

(4) Boehr, D. D.; McElheny, D.; Dyson, H. J.; Wright, P. E. Science 2006, 313, 1638-1642.

(5) Henzler-Wildman, K. A.; Thai, V.; Lei, M.; Ott, M.; Wolf-Watz, M.; Fenn, T.; Pozharski, E.; Wilson, M. A.; Petsko, G. A.; Karplus, M.; Hubner, C. G.; Kern, D. Nature 2007, 450, 838-844.

(6) Adamczyk, A. J.; Cao, J.; Kamerlin, S. C. L.; Warshel, A. Proc. Natl. Acad. Sci. USA 2011, 108, 14115-14120.
(7) Glowacki, D. R.; Harvey, J. N.; Mulholland, A. J. Nature Chem. 2012, 4, 169-176.

(8) Kohen, A.; Cannio, R.; Bartolucci, S.; Klinman, J. P. Nature 1999, 399, 496-499.

(9) Basran, J.; Sutcliffe, M. J.; Scrutton, N. S. Biochemistry 1999, 38, 3218-3222.

(10) Maglia, G.; Allemann, R. K. J. Am. Chem. Soc. 2003, 125, 1337213373.

(11) Silva, R. G.; Murkin, A. S.; Schramm, V. L. Proc. Natl. Acad. Sci. USA 2011, 108, 18661-18665.

(12) Kipp, D. R.; Silva, R. G.; Schramm, V. L. J. Am. Chem. Soc. 2011, 133, 19358-19361.

(13) Suarez, J.; Schramm, V. L. Proc. Natl. Acad. Sci. USA 2015, 112, $11247-11251$.

(14) Zoi, I.; Suarez, J.; Antoniou, D.; Cameron, S. A.; Schramm, V. L.; Schwartz, S. D. J. Am. Chem. Soc. 2016, 138, 3403-3409.

(15) Pudney, C. R.; Guerriero, A.; Baxter, N. J.; Johannissen, L. O.; Waltho, J. P.; Hay, S.; Scrutton, N. S. J. Am. Chem. Soc. 2013, 135, $2512-$ 2517.

(16) Toney, M. D.; Castro, J. N.; Addington, T. A. J. Am. Chem. Soc. 2013, 135, 2509-2511.

(17) Luk, L. Y.; Javier Ruiz-Pernia, J.; Dawson, W. M.; Roca, M.; Loveridge, E. J.; Glowacki, D. R.; Harvey, J. N.; Mulholland, A. J.; Tunon, I.; Moliner, V.; Allemann, R. K. Proc. Natl. Acad. Sci. USA 2013, 110, 16344-16349.

(18) Ruiz-Pernia, J. J.; Luk, L. Y.; Garcia-Meseguer, R.; Marti, S.; Loveridge, E. J.; Tunon, I.; Moliner, V.; Allemann, R. K. J. Am. Chem. Soc. 2013, 135, 18689-18696.

(19) Wang, Z.; Singh, P.; Czekster, C. M.; Kohen, A.; Schramm, V. L. J. Am. Chem. Soc. 2014, 136, 8333-8341.

(20) Luk, L. Y.; Ruiz-Pernia, J. J.; Adesina, A. S.; Loveridge, E. J.; Tunon, I.; Moliner, V.; Allemann, R. K. Angew. Chem. 2015, 54, 9016-9020.

(21) Wang, Z.; Antoniou, D.; Schwartz, S. D.; Schramm, V. L. Biochemistry 2016, 55, 157-166.

(22) Francis, K.; Sapienza, P. J.; Lee, A. L.; Kohen, A. Biochemistry 2016, 55, 1100-1106.

(23) Rokop, S.; Gajda, L.; Parmerter, S.; Crespi, H. L.; Katz, J. J. Biochim. Biophys. Acta 1969, 191, 707-715.

(24) Khan, H.; Harris, R. J.; Barna, T.; Craig, D. H.; Bruce, N. C.; Munro, A. W.; Moody, P. C.; Scrutton, N. S. J. Biol. Chem. 2002, 277, 21906-21912.

(25) Pudney, C. R.; Hay, S.; Levy, C.; Pang, J. Y.; Sutcliffe, M. J.; Leys, D.; Scrutton, N. S. J. Am. Chem. Soc. 2009, 131, 17072-17073.

(26) Pudney, C. R.; Lane, R. S. K.; Fielding, A. J.; Magennis, S. W.; Hay, S.; Scrutton, N. S. J. Am. Chem. Soc. 2013, 135, 3855-3864.

(27) Toogood, H. S.; Scrutton, N. S. Curr. Opin. Chem. Biol. 2014, $19,107-115$.

(28) Toogood, H. S.; Fryszkowska, A.; Hulley, M.; Sakuma, M.; Mansell, D.; Stephens, G. M.; Gardiner, J. M.; Scrutton, N. S. ChemBioChem 2011, 12, 738-749.

(29) Pudney, C. R.; Hay, S.; Scrutton, N. S. FEBS J. 2009, 276, 47804789.

(30) Hobbs, J. K.; Jiao, W.; Easter, A. D.; Parker, E. J.; Schipper, L. A.; Arcus, V. L. ACS Chem. Biol. 2013, 8, 2388-2393.

(31) Arcus, V. L.; Prentice, E. J.; Hobbs, J. K.; Mulholland, A. J.; Van der Kamp, M. W.; Pudney, C. R.; Parker, E. J.; Schipper, L. A. Biochemistry 2016, 55, 1681-1688.

(32) Meadows, C. W.; Tsang, J. E.; Klinman, J. P. J. Am. Chem. Soc. 2014, 136, 14821-14833.

(33) Meadows, C. W.; Ou, R.; Klinman, J. P. J. Phys. Chem. B 2014, $118,6049-6061$.

(34) Hardman, S. J.; Pudney, C. R.; Hay, S.; Scrutton, N. S. Biophy. J. 2013, 105, 2549-2558.

(35) Salzmann, S.; Martinez-Junza, V.; Zorn, B.; Braslavsky, S. E.; Mansurova, M.; Marian, C. M.; Gartner, W. J. Phys. Chem. A 2009, 113, 9365-9375.

(36) Kao, Y. T.; Saxena, C.; He, T. F.; Guo, L.; Wang, L.; Sancar, A.; Zhong, D. J. Am. Chem. Soc. 2008, 130, 13132-13139. 
(37) Potasek, M. J.; Hopfield, J. J. Proc. Natl. Acad. Sci. USA 1977, 74, 3817-3820.

(38) Bixon, M.; Jortner, J. J. Phys. Chem. 1986, 90, 3795-3800.

(39) Hay, S.; Pudney, C. R.; McGrory, T. A.; Pang, J.; Sutcliffe, M. J.; Scrutton, N. S. Angew. Chem. 2009, 48, 1452-1454.

(40) Pudney, C. R.; Johannissen, L. O.; Sutcliffe, M. J.; Hay, S.; Scrutton, N. S. J. Am. Chem. Soc. 2010, 132, 11329-11335.

(41) Johannissen, L. O.; Scrutton, N. S.; Sutcliffe, M. J. Angew. Chem. 2011, 50, 2129-2132.

(42) Antoniou, D.; Ge, X.; Schramm, V. L.; Schwartz, S. D. J. Phys. Chem. Lett. 2012, 3, 3538-3544.

(43) Hedison, T. M.; Leferink, N. G. H.; Hay, S.; Scrutton, N. S. ACS Catal. 2016, 5170-5180.

(44) Pudney, C. R.; Hay, S.; Sutcliffe, M. J.; Scrutton, N. S. J. Am. Chem. Soc. 2006, 128, 14053-14058. 
Table of Contents artwork

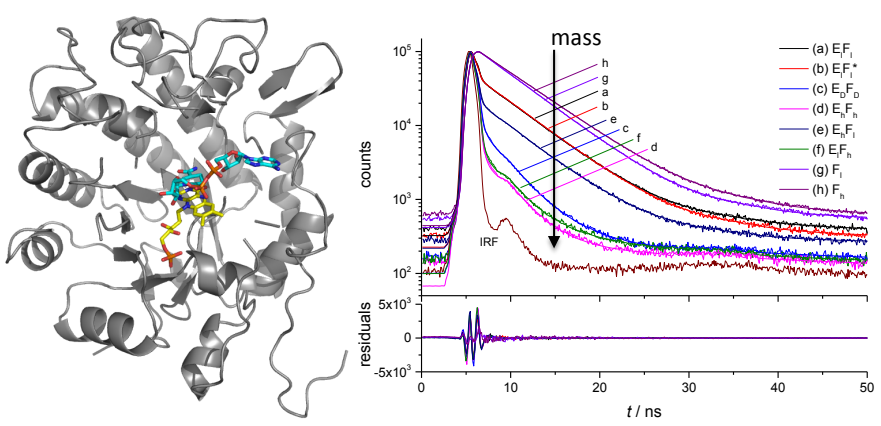

